\title{
HAEMATOLOGICAL AND BIOCHEMICAL ALTERATIONS IN HILL. BULLS INFECTED WITH CLOSTRIDIUM CHAUVOEI
}

\author{
K. P. SINGH, ${ }^{1}$ N. S. PARIHAR, ${ }^{2}$ K. CHARAN ${ }^{3}$ and B. N. TRIPATHI \\ Division of Pathology, Indian Veterinary Research Institute, Izatnagar 243122, India
}

Received Fuly 25, 1991

\begin{abstract}
Singh K. P., N. S. Parihar, K. Charan, B. N. Tripathi: Haematological and Biochemical Alterations in Hill bulls Infected with Clostridium chauvoei. Acta vet. Brno, 62, 1993: 89-94.

Hill bulls infected with $\mathrm{Cl}$. chauvoei developed haemoconcentration as evidenced by significantly increased total erythrocyte count $\left(8.66 \times 10^{12} / 1\right)$, haemoglobin $(150 \mathrm{~g} / \mathrm{l})$ and haematocrit $(0.44 \mathrm{l} / \mathrm{l})$ associated with fluid exudation in subcutaneous tissues and muscles and serous effusions in the body cavities. Thrombocyte and total leukocyte count were significantly decreased initially at 1 to 3 days post infection (DPI) $\left(180.0 \times 10^{\circ} / 1\right.$ and $4.47 \times 10^{9} / 1$ respectively) but increased after $3 \mathrm{DPI}$ onwards, possibly due to adverse effects of toxin produced by the organisms. The neutrophil count was significantly increased $\left(6.86 \times 10^{\circ} / 1\right)$ and lymphocytes correspondingly decreased $\left(4.91 \times 10^{\circ} / 1\right)$. The values for creatine phosphokinase $(\mathrm{CPK}$, 2,800 IU/1), aspartate aminotransferase (AST, $223 \mathrm{IU} / 1$ ), alanine aminotransferase (ALT, $66 \mathrm{IU} / \mathrm{l})$ and lactate dehydrogenase $(\mathrm{LDH}, 201 \mathrm{IU} / \mathrm{l})$ were significantly increased. CPK, AST and LDH were attributed to muscle damage both skeletal and to a little extent cardiac and the increased ALT values appeared to be due to hepatic damage. Blood glucose values did not show any definite pattern, increased in culture inoculated group $(8.1 \mathrm{mmol} / \mathrm{l})$ while decreased $(4.1 \mathrm{mmol} / \mathrm{l})$ in groups inoculated intramuscularly with spores or toxin or fed spores.
\end{abstract}

Experimental infection, Clostridium chauvoei spores, toxin, Hill bulls

In Clostridium chauvoei infection, information on haematological and biochemical changes is: meagre. It is likely that some of these values might have diagnostic importance in clinical cases. Pemberton et al. (1974) reported changes in the clinical values during infection set up by challenging the vaccinated cattle $\mathrm{i} / \mathrm{m}$ with $\mathrm{Cl}$. chauvoei spores mixed with calcium chloride. Anders on et al. (1976) and Mouthon and Magat (1976) reported increased activity of certain serum enzymes following muscular degeneration (diseases not specifically the clostridial myonecrosis) black quarter. The present study describes certain haematological and biochemical parameters in hill bulls variously infected with $\mathrm{i} / \mathrm{m}$ injection of $\mathrm{Cl}$. chauvoei spores (culture) toxin and oral feeding with spores.

\section{Materials and Methods}

Thirty apparently healthy hill bulls (local nondescript, short, light cattle available in hilly Garhwal and Kumaon regions of Himalayas) 2-to 3-years-old and $100-150 \mathrm{~kg}$ in body mass were used. They were thoroughly examined for any clinical signs and variations in body temperatures. The animals were randomly divided into five groups of 6 animals each.

1. Six animals in this group were treated as controls. Each animal was injected $100 \mathrm{ml}$ sterilized Robertson's cooked meat (RCM) medium along with equal amount of $5 \%$ sterilized calcium chloride solution i. m. at 4 sites in thigh and hind quarter muscles. 
2. Six animals in this group were given $800 \mathrm{ml}\left(4.6 \times 10^{4}\right.$ spores $\left./ \mathrm{ml}\right)$ spore suspension each orally. After 30 days each animal was inoculated at 4 sites in the hind quarter and thigh muscles with $25 \mathrm{ml}$ each of $5 \%$ sterilized calcium chloride.

3. Each animal in this group was injected $100 \mathrm{ml}$ spore suspension $\left(4.6 \times 10^{4}\right.$ spores $\left./ \mathrm{ml}\right)$ mixed with equal volume of $5 \%$ sterilized calcium chloride i. $\mathrm{m}$. at 4 sites in hind quarter and thigh muscles.

4. Three animals each in this group were given $50 \mathrm{ml}\left(5.0 \times 10^{9} \mathrm{c}\right.$. f. u/ml $)$ of 36 hour old culture mixed with equal volume of $5 \%$ sterilized calcium chloride i. $\mathrm{m}$. at 4 places in thigh and hind quarter muscles. Another three animals were treated similarly but with double doses.

5. This group of six animals was injected $100 \mathrm{ml}$ Seitz filtered crude toxin ( 100 mouse $\mathrm{MLD} / \mathrm{ml}$ ) at 4 places i. $\mathrm{m}$. in thigh and hind quarter muscles.

The haematological parameters studied were total erythrocyte count (TEC), haemoglobin (Hb), haematocrit, thrombocyte count, total leukocyte count (TLC) and differential leukocyte count (DLC) after Jain (1986). For these parameters $2 \mathrm{ml}$ of blood was collected daily by venipuncture using sodium salt of ethylenediaminetetraacetic acid (EDTA) as the anticoagulant a $1-2 \mathrm{mg} / \mathrm{ml}$. For blood serum biochemical parameters about $6 \mathrm{ml}$ each of blood was collected daily by venipuncture in sterile glass test tubes and kept in slanting position. The serum was collected and preserved at $-20^{\circ} \mathrm{C}$. Blood glucose was estimated by Ames Dextrometer (Kyoto Daiichi Kagaku Co. Ltd. Kyoto, Japan) using Dextrostix strips manufactured by $\mathrm{M} / \mathrm{s}$ Miles India Ltd., Baroda. Serum samples were analysed for creatine phosphokinase (CPK), aspartate aminotransferase (AST), alanine aminotransferase (ALT), lactate dehydrogenase (LDH), total protein and albumin by Chemetrics analyzer (Chemetrics Corporation, USA) using Autopak reagent kits supplied by $\mathrm{M} / \mathrm{s}$ Miles India Ltd., Baroda.

Means and standard errors were computed for individual groups. For purposes of comparison, the values of all animals at 0 DPI were pooled together. The data were analysed by analysis of variance using " $F$ " test.

\section{Results}

The disease was produced in all 4 infected groups with a few animals succumbing. i. e. 1 each in 2 nd and 5 th and 2 each in 3rd and 4th groups. The infected animals exhibited swelling and lameness by 20 hours of inoculation with rise in body temperature $\left(104^{\circ} \mathrm{F}\right)$. The subcutaneous tissue was severely oedematous, gelatinized and contained large volumes of serosanguineous exudate. The muscles became necrosed, gangrenous and blackened. The animals became recumbent in 10 to 36 hours and died within 2 to 4 DPI. The remaining animals revealed mild to moderate symptoms and were sacrificed in 5 to 9 DPI.

\section{a) Haematological changes}

The pooled preinoculation values averaged $6.49 \times 10^{12} / 1$ for TEC, $126.0 \mathrm{~g} / 1$ for $\mathrm{Hb}, 0.35 \mathrm{l} / 1$ for haematocrit, $268.0 \times 10^{9} / 1$ for thrombocyte count, $8.93 \times 10^{9} / 1$ for TLC, $2.23 \times 10^{9} / 1$ for neutrophils, $6.45 \times 10^{9} / 1$ for lymphocytes, $0.13 \times 10^{9} / 1$ for monocytes and $0.1 \times 10^{9} / 1$ for eosinophils. The TEC level was significantly increased $\left(8.66 \times 10^{12} / 1^{*}\right)$ from 3 DPI onwards in spore and culture injected hill bulls. In spore fed and toxin injected hill bulls the increasing TEC values $(6.57 \times$ $\left.\times 10^{12} / 1\right)$ were noticed from $5 \mathrm{DPI}$ onwards. The $\mathrm{Hb}$ values were significantly increased $\left(150 \mathrm{~g} / 1^{*}\right)$ in spore and culture injected hill bulls at 3 and $4 \mathrm{DPI}$, and then decreased. The haematocrit values were significantly increased $\left(0.441 / 1^{*}\right)$ in all the infected groups from 2 DPI onwards. There was a general decreasing trend in thrombocyte values in all the infected groups. And the values were significantly decreased $\left(186 \times 10^{9} / 1^{*}\right)$ in spore fed, spore injected and culture injected hill bulls at 3 DPI. The TLC values were significantly decreased $(4.47 \times$ $\times 10^{9} / 1^{*}$ ) from 1 to $3 \mathrm{DPI}$ in all the infected groups and then became normal after 3 DPI onwards (Fig. 1). There was a gradual increasing trend in neutrophils with corresponding decrease in lymphocytes (Fig. 2). The neutrophils were significantly increased $\left(6.86 \times 10^{9} / 1^{*}\right)$ in spore injected and culture injected groups 

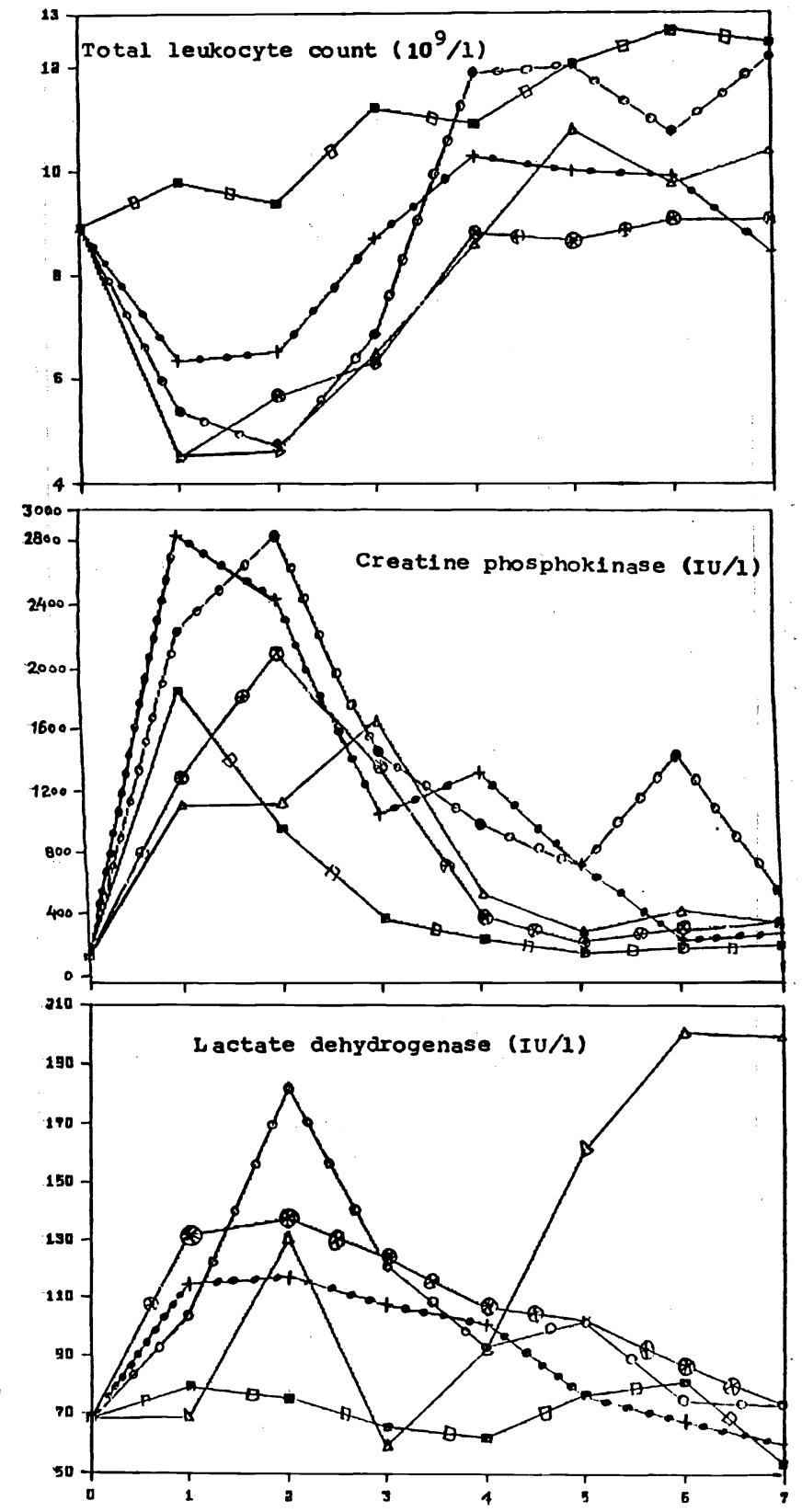

F1g. 1 마므 Intramuscular RCM and calcium chloride - Oral spores and intramuscular calcium chloride 0-0 Intramuscular spores and calclum chloride $\Delta-\Delta-\Delta$ Intramuclar culture and calcium chloride $\otimes-\otimes$ Intramuscular toxin 


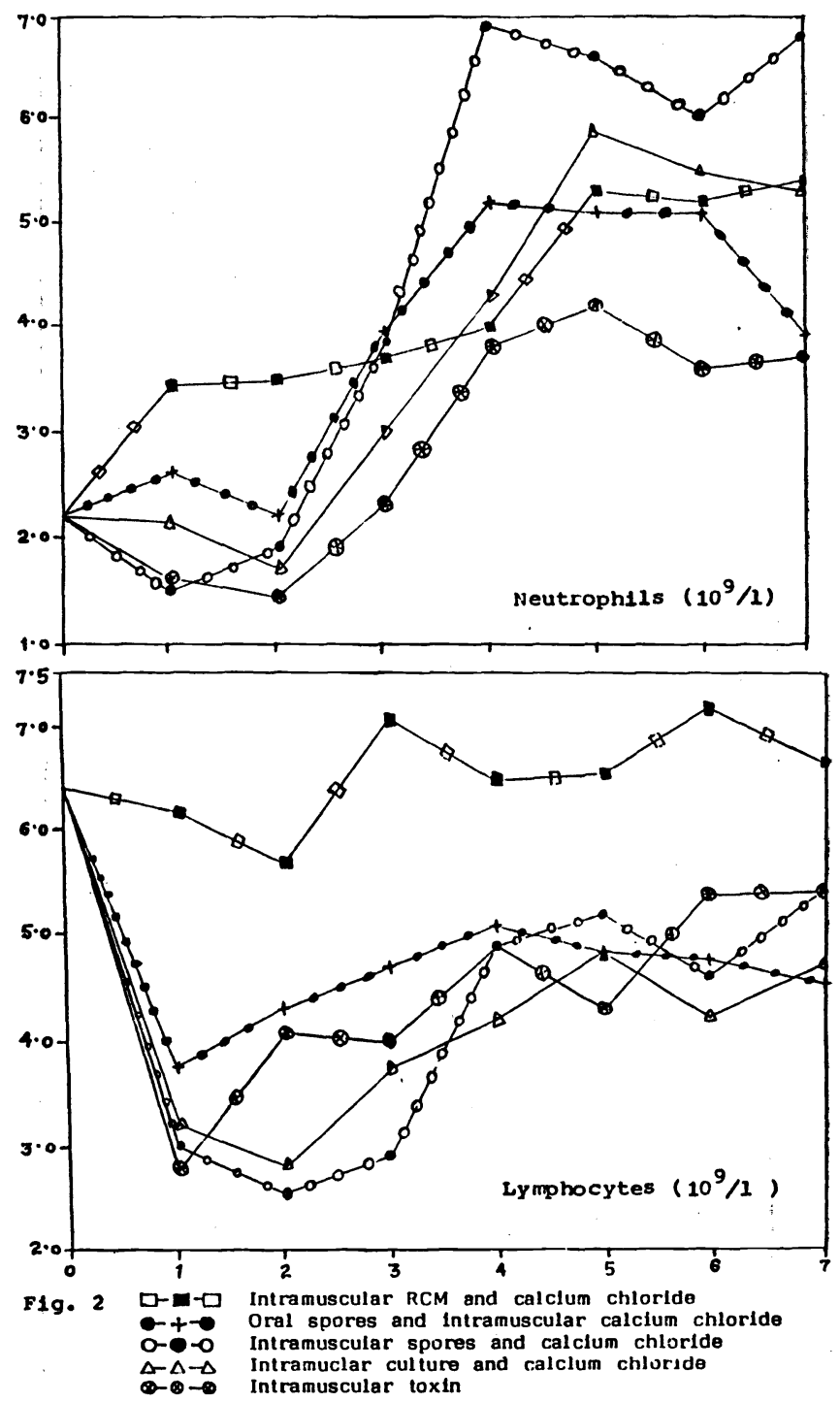

at 3 and 4 DPI and in spore fed group $\left(5.2 \times 10^{9} / 1^{*}\right)$ at $4 \mathrm{DPI}$. The lymphocytes were significantly decreased $\left(4.91 \times 10^{9} / 1^{*}\right)$ in spore fed, spore injected and culture injected groups at 3 and 4 DPI.

b) Biochemical changes

The pooled preinoculation average values were $6.27 \mathrm{mmol} / 1$ for blood glucose, $126.70 \mathrm{IU} / 1$ for $\mathrm{CPK}, 42.77 \mathrm{IU} / 1$ for $\mathrm{AST}, 11.70 \mathrm{IU} / 1$ for $\mathrm{ALT}, 68.50 \mathrm{IU} / 1$ for LDH, $72.7 \mathrm{~g} / 1$ for total protein, $38.6 \mathrm{~g} / 1$ for albumin, $33.7 \mathrm{~g} / 1$ for globulin and 1.15 for $\mathrm{A} / \mathrm{G}$ ratio. The blood glucose values were significantly increased $\left(8.0 \mathrm{~m} \mathrm{~mol} / 1^{*}\right)$ in culture injected hill bulls from 1 to $3 \mathrm{DPI}$, while significantly decreased $\left(4.85 \mathrm{~m} \mathrm{~mol} / 1^{*}\right)$ at $6 \mathrm{DPI}$. These values were also decreased in spore 
fed and spore injected groups. The values for CPK, AST and ALT were significantly increased in initial stages from 1 to 4 DPI and then gradually decreased to 7 DPI in all infected groups. The maximum peak for CPK $(2800 \mathrm{IU} / 1)$ was noticed in spore fed and spore injected hill bulls at 1 to 2 DPI (Fig. 1). The AST values were very much increased and the maximum was $223 \mathrm{IU} / \mathrm{l}^{*}$ in toxin injected group at $3 \mathrm{DPI}$ and $183 \mathrm{IU} / 1^{*}$ in spore injected group at similar time intervals. The ALT values were significantly increased in spore fed group (as high as $66 \mathrm{IU} / 1^{*}$ ) and in spore injected group (max. $46 \mathrm{IU} / 1^{*}$ ) at 1 and $2 \mathrm{DPI}$. Though the LDH values were found increased in all the infected groups but were statistically significant in spore injected and toxin injected hill bulls (121 to $124 \mathrm{IU} / 1^{*}$ ) at $3 \mathrm{DPI}$ (Fig. 1). In culture injected group increased LDH value $\left(201 \mathrm{IU} / 1^{*}\right)$ was noticed at $6 \mathrm{DPI}$. The total protein values were found decreased in spore injected and culture injected $(60.8 \mathrm{~g} / 1)$ groups but increased in toxin injected and spore fed groups $(77.3 \mathrm{~g} / 1)$.

\section{Discussion}

The neutrophil count and haemogram (TEC, $\mathrm{Hb}$ and haematocrit) were significantly higher in all infected hill bulls which is in consonance with the bacterial nature of infection and haemoconcentration following sickness (Ritchie 1990 and Pathak 1990). The TLC, lymphocytes and thrombocytes were significantly decreased which were not unlike the findings of Pemberton et al. (1974). In their studies decreased $\mathrm{Hb}$ and haematocrit values were noticed in survivors who regained normal levels by 40 DPI. Since the survivors in this study were sacrificed at the most at 9 DPI, these haematological observations cannot be commented upon. The sickness was characterized by fluid exudation in subcutaneous tissue and muscles and serous effusions in the body cavities aggravating the haemoconcentration. The probable cause for thrombocytopenia was toxaemia as also suggested by Ritchie (1990) and for decreased TLC Jubb et al. (1985) opined that leukocytes were destroyed by diffusing toxins in tissues. The role of diffusing toxins on circulating leukocytes and thrombocytes and their subsequent effects need to be looked into further.

CPK, AST, ALT and LDH values revealed rising trends following infection, were maximum at 1 to 4 DPI and then gradually decreased but remained above the initial values. The higher concentrations of above serum enzymes are not unusual and are in close agreement with the findings of Pemberton et al. (1974), Keller (1974) and Anderson et al. (1976) in bovines. Injury to muscles and/or liver invariably result in increased values of these enzymes (Mouthon and Magat 1976; Anderson et al. 1976) and the present cases were no exception in respect of muscle damage, both to skeletal and, to little extent, to cardiac. The increased CPK, AST and LDH levels were apparently related with muscle damage and the increased ALT values appeared to be due to the hepatic damage as suggested by the earlier workers (Pemberton et al. 1974) and also proven on histopathological examination. The blood glucose levels were significantly elevated in culture injected hill bulls at 1 to 3 DPI while significantly decreased at 6 DPI. Stockl et al. (1965) also recorded increased blood sugar levels in initial stages and lowered values in later stages in their experimental studies with $\mathrm{Cl}$. chauvoei and $\mathrm{Cl}$. septicum infection in sheep. Disturbances in carbohydrate meta-

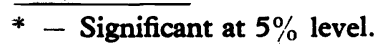


bolism caused by these organisms were attributed as the reason for varying values recorded but the same were not detailed. In other groups the glucose values were decreased significantly. Since glucose metabolism is usually affected in clostridial infection, this aspect deserves further probe.

Possibility of inadequate synthesis and increased degradation of proteins was suggested by Lyaushkin (1968) in guinea pigs experimentally infected with $\mathrm{Cl}$. chauvoei and the same appeared to be the case here in the hill bulls intramuscularly inoculated with either culture or spores. In other treatments the alterations were insignificant. Perusal of the available literature reveals that adequate studies are lacking in respect of biochemical changes in Cl. chauvoei infection and, therefore, this aspect needs further systematic research efforts to be able to draw valid conclusions.

\section{Acknowledgement}

We thank the Head, Division of Pathology; Head, Division of Bacteriology and Mycology; Joint Directors and Director of the Institute for providing the necessary facilities and encouragement for this work.

\section{References}

ANDERSON, P. H.-BERRETT, S.-PATTERSON, D. S. P.: The significance of elevated plasma creatine phosphokinase activity in muscle disease of cattle. J. Comp. Path., 86, 1976: $531-538$

JAIN, N. C.: Schalm's Veterinary Haematology. Lea and Febiger Philadelphia, U.S.A. 4th edn., 1986: pp. 20-65

JUBB, K. V. F. - KENNEDY, P. C. - PALMER, N.: Pathology of Domestic Animals. Academic Press Inc. London, 3rd edn. Vol. I, 1985: pp. 184

KELLER, P.: Lactate dehydrogenase isoenzymes in normal bovine serum and during experimental liver and muscle damage. Res. Vet. Sci., 17, 1974: 49-58

LYAUSHKIN, A. V.: Pathogenesis of black leg in cattle. Trudy Vses. Inst. eksp. Vet. 35, 1968: 228-239, Abstr. Vet. Bull., 40, 1970: 4319

MOUTHON, G.-MAGAT, A.: Biochemical diagnosis of degenerative myopathies in young cattle. Recueil de Med. Vet. 152 (7/8), 1976: 451-455, Abstr. Vet. Bull., 47, 1977: 1577

PATHAK, D. C.: Studies on the pathology of enterotoxaemia in sheep due to Cl. perfringens. type D, Ph. D. Thesis, I.V.R.I., Izatnagar. 1990, pp. 93-94

PEMBERTON, J. R.-BATES, F.-MATSON, R.-MACHEAK, M. E.-HIGBE, J.: Changes in clinical values cattle infected with $\mathrm{Cl}$. chauvoei I. Preliminary report, II. Clinical relationship during infection. Am. J. Vet. Res., 35, 1974: $1037-1044$

RITCHIE, A. C.: Boyd's Textbook of Pathology. Lea and Febiger Philadelphia/London, 9th edn. Vol. I, 1990: pp. $100 \& 351$

STOCKL, W.-WEISER, M. - GEIGENMULLER, H.-GRISSEMANN, A.: Pathogenesis of $\mathrm{Cl}$. septicum and $\mathrm{Cl}$. chauvoei infections in sheep. Zentbl. Vet. Med. 12A, 1965:580-588, Abstr. Vet. Bull., 36, 1966: 1.715 